\title{
Personal Income Tax Revenue and Nigeria's Aggregate Earnings
}

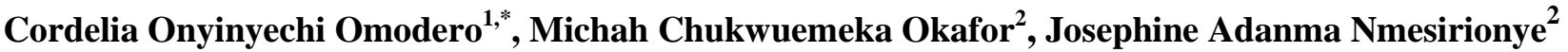 \\ ${ }^{1}$ Department of Accounting, College of Management and Social Sciences, Covenant University Ota, Ogun State, Nigeria \\ ${ }^{2}$ Department of Accounting, College of Management Sciences, Michael Okpara University of Agriculture Umudike Umuahia Abia \\ State, Nigeria
}

Received June 29, 2021; Revised August 15, 2021; Accepted August 30, 2021

\section{Cite This Paper in the following Citation Styles}

(a): [1] Cordelia Onyinyechi Omodero, Michah Chukwuemeka Okafor, Josephine Adanma Nmesirionye , "Personal Income Tax Revenue and Nigeria's Aggregate Earnings," Universal Journal of Accounting and Finance, Vol. 9, No. 4, pp. 783 - 789, 2021. DOI: 10.13189/ujaf.2021.090424.

(b): Cordelia Onyinyechi Omodero, Michah Chukwuemeka Okafor, Josephine Adanma Nmesirionye (2021). Personal Income Tax Revenue and Nigeria's Aggregate Earnings. Universal Journal of Accounting and Finance, 9(4), 783 - 789. DOI: 10.13189/ujaf.2021.090424.

Copyright $\bigcirc 2021$ by authors, all rights reserved. Authors agree that this article remains permanently open access under the terms of the Creative Commons Attribution License 4.0 International License

\begin{abstract}
The contribution of personal income tax to gross national income is assessed in this study. Over the years, tax revenue has been an important government source of income to finance public goods and services. In Nigeria, the tax structure includes personal income tax (PIT) as well as other direct and indirect taxes. There is PIT collection by both the state and federal governments. This study examines the influence of PIT on aggregate income of the country from 2011 to 2020 using ordinary least squares method. The dependent variable is the gross national earnings while the independent variable is the personal income tax collected at the federal government level in Nigeria. The study finds corruption and inflation as two useful control variables that have direct influence and link with individuals' tax compliance in Nigeria. The data sources include the Organization for Economic Co-operation and Development (OECD) for PIT figures, Transparency International (TI) for Corruption Perceptions Index (CPI) data and World Bank Economic Indicators for Gross National Income (GNI) and inflation statistics. The empirical findings reveal that PIT has a significant positive influence on the gross national income. The moderating variables applied are not significant and could not explain the vicissitudes in the gross national earnings. The study recommends improvement in the PIT administration to boost tax revenue collections and remittances to the government treasury. Further suggestion by this study is that corruption and inflation should be minimized to enhance PIT collection at both federal and state
\end{abstract}

government levels.

Keywords Gross National Revenue, Personal Income Tax, Corruption, Inflation, Remittances

JEL Classification Codes: P44, H71, H24, F24, D73

\section{Introduction}

Tax income is seen as a key and powerful tool for boosting a country's economic growth. The taxation system is an effective and powerful avenue for mobilizing a country's internal resources. The primary goal of a taxation system is to decrease income inequality, finance public goods and services in an economy, encourage effective resource allocation, and economic stability (Amin, Chen \& Huang, 2018). Taxation is a fiscal policy instrument used by government of nations to generate revenue. The revenue derived from tax is purely used by the government to execute expenditure functions. Thus, the government implements tax policies that will enable her finance public investments and satisfy other social needs [1]. In a nutshell, the government directly levies taxes on individuals and firms to promote economic growth [2]. Considering tax issues in other economies of the world, [3] believe that the effect of taxation on economic growth depends on the structure and level of 
taxation driving an economy. In line with this study, Personal Income Tax (PIT) is part of a nation's tax structure which is an important source of public revenue and designed to stimulate economic growth. Personal income tax administration is expected to be cost effective and should not distort the normal flow of economic activities. In Nigeria, personal income tax is a deduction from employment incomes and other incomes an individual earns from a business endeavor. Personal Income Tax is a direct tax levied on the earnings of an individual, which might be a person or a single proprietorship.

The rate of PIT due is determined by the amount of taxable income for which the individual is responsible. Taxable income is the basis for the income tax system levies and determines the amount of tax a person must pay in a certain calendar year. In general, it comprises part or all revenue less costs and other deductions. The Nigerian PIT laws were last amended in 2011. Former President Goodluck Jonathan signed into law a revised PIT Act during his administration to replace the contentious portions, particularly Section 33 of the Personal Income Tax Act 1993, which deals with: Personal Relief, Relief for Children, Relief for Dependent Relatives, and so on. They have been replaced with a Consolidated Relief Allowance (CRA) of $\$ 200,000$ plus $20 \%$ of Gross Income (G.I). OR $1 \%$ of G.I. PLUS $20 \%$ of G.I., whichever is greater. The minimum tax is now one percent of gross income (adjusted), rather than 0.5 percent. For the purpose of applicable tax rate, $7 \%$ is applied to the first $\$ 300,000$; $11 \%$ for the next $\$ 300,000 ; 15 \%$ for the next $\$ 500,000 ; 19 \%$ for the next $\$ 500,000 ; 21 \%$ for the next $\$ 1,600,000$ and $24 \%$ for an amount above $\$ 3,200,000$. The only allowed income deductions as on the 6th Schedule of PITA 2011 include: National Housing Funds Contributions, National Health Insurance Contributions, Life Assurance Premium, National Pension Contribution and Gratuities.

The effect of personal income tax has not been widely studies as expected. This study is meant to contribute to the expansion of literature on personal income tax effectiveness in national income improvement. Other studies stressed on PIT effect on economic growth and infrastructural development. In this current research, the focus is to examine the extent to which PIT contributes to national aggregate revenue. Therefore the following assumption ensue:

Ho1: The research initiates an assumption that PIT does not improve the national total revenue.

The rest of the other variables are employed for moderation purposes.

\section{Literature Review}

Szarowska [4] used the standard scientific method to assess the importance and disparities of personal income taxation in 21 selected European countries, OECD and European Union members. The results confirmed the relevance of PIT by showing that each $1 \%$ increase on PIT increased the rate by $0.5 \%$. Kalaš, Mirović and Andrašić [5] examined American data from 1996 to 2016 and found that increases in tax revenues and social security payments had a substantial influence on economic growth, however personal income tax and corporate income tax had little effect.Palic et al. [3] assessed the long-run influence of personal income taxation on economic development of Croatia. The study adopted Johansen co-integration technique and Error Correction Model to examine the data that spanned from 2006 to 2016. From the result, personal income taxation in Croatia has a significant negative impact on the economic growth of Croatia. Nonvide and Amegnaglo [6] utilized the OLS method to show that tax revenues boosted Benin's economic development. Stoilova [7] applied pooled panel data that covered a period from 1996 - 2013 to investigate tax structure and economic growth in 28 member states of the European Union. The regression result disclosed that personal income tax, property and consumption taxes contributed positively and substantially to economic growth. Cornia, Johnson and Nelson [8] used a series of simulations based on twenty-one years of tax returns, to show that tax reform initiatives failed to significantly reduce the volatility of personal income tax collections by preserving exemptions and deductions. These simulations also demonstrated that the originally planned flat income tax with no exclusions or deductions would have reduced volatility at the expense of slowing growth.

Amin et al. [9] compared the relationship between personal income tax and economic growth in China and Pakistan using Granger Causality frameworks. The result showed that in Pakistan and China, PIT had a positive influence on economic growth, among others. Baltais and Braks [10] researched on the effect of personal income tax progressivity using data that covered a period from 2000 - 2012. The sample of the study was drawn from OECD countries and focused on non-linear relationship between PIT and RGDP. The empirical analysis provided evidence that PIT had a negative effect on output while non-linear relationship was also noticed accordingly. Mcnabb [11] utilized the ICTD UNU-WIDER Government Revenue Dataset in a panel of 100 nations to challenge and expand on current results on the relationship between tax regimes and economic development. The findings indicated that revenue-neutral increases in income taxes were linked with weaker long-run GDP growth and that revenue-neutral reductions in trade taxes were not necessarily beneficial.

Korkmaz et al. [2] examined the impact of direct and indirect taxes on the growth of Turkish economy. The study employed ARDL model to analyze a quarterly data that spanned from 2006 - 2018. The findings showed that 
direct taxes exhibited a significant negative impact on economic growth. On the other hand, the result from the analysis confirmed that indirect taxes had a significant positive influence on economic growth. Neog and Gaur [12] examined tax structure and economic growth in 14 Indian states using panel pool mean group estimation. The findings showed that income tax and commodity - service tax had negative effects while property and capital transaction tax exerted significant positive effect on the state economic growth.

In Nigeria, Egbunike, Emudainohwo, and Gunardi [13] studied the economies of Nigeria and Ghana between 2000 and 2016 and discovered that tax collections boosted economic development. Adeyemi and Mieseigha [14] employed vector auto-regression to evaluate the effect of PIT on GDP from 1987 - 2017. The findings revealed that PIT contributed immensely to Nigeria's economic growth within the period covered by the study. Ade and Adegbie [15] examined contribution of PIT to infrastructural development in Lagos State. The study showed that PIT had a significant positive effect on infrastructural provisions.

\section{Data and Methodology}

Using the OLS technique, this study analyzes the contribution of personal income tax to Nigeria's total national income growth. The Ordinary Least Squares is found very useful as the study intends expressing the influence of each predictor variable on the response element. Annual data sets from 2011 to 2020 were utilized to do the calculation. The PIT statistics employed in this analysis were taken from the OECD website, while the CPI data were obtained from the Transparency International and the inflation data were gathered from the World Bank Economic Indicators. For consistent and trustworthy empirical results, all of these variables were transformed into a natural logarithm [16]. The following model was developed for empirical estimation:

$$
\mathrm{GNI}=\mathrm{f}(\mathrm{PIT}, \mathrm{CPI}, \mathrm{INF})
$$

In this equation, GNI (Aggregate national income) is the model's dependent variable. The response variable is the PIT (Personal Income Tax). Other selected predictor variables moderating in the estimation include CPI (Corruption Perception Index) and INF (Inflation).

Table 1 provides statistical description of the variables used in this study. The GNI, PIT, CPI and INF have the mean values of 5.6, 4.7, 1.4, and 0.9 respectively. The standard deviation values of GNI, PIT, CPI and INF are $0.09,0.15,0.02$ and 0.22 accordingly. The outcome of the standard deviation implies a lower spread of the data sets. On Skewness, there is a negative skewness for GNI, CPI and INF while PIT is moderately and positively skewed. Most importantly, the result of the Kurtosis and Jarque-Bera shows there is a normal distribution as the probabilities of all the variables are all above $5 \%$ level of significance. Figure 1 also provides confirmation of the normality of the data distribution.

Table 1. Descriptive Statistics

\begin{tabular}{|c|c|c|c|c|}
\hline & LOG_GNI & LOG_PIT & LOG_CPI & LOG_INF \\
\hline Mean & 5.685640 & 4.770877 & 1.416970 & 0.907475 \\
\hline Median & 5.701300 & 4.740875 & 1.423169 & 0.993995 \\
\hline Maximum & 5.813716 & 5.032144 & 1.447158 & 1.213326 \\
\hline Minimum & 5.513279 & 4.512736 & 1.380211 & 0.456922 \\
\hline Std. Dev. & 0.099514 & 0.156993 & 0.021716 & 0.226106 \\
\hline Skewness & -0.374782 & 0.201355 & -0.446528 & -0.802890 \\
\hline Kurtosis & 2.023885 & 2.245456 & 1.982961 & 2.644082 \\
\hline Jarque-Bera & 0.631104 & 0.304797 & 0.763299 & 1.127169 \\
\hline Probability & 0.729386 & 0.858646 & 0.682734 & 0.569165 \\
\hline Sum & 56.85640 & 47.70877 & 14.16970 & 9.074752 \\
\hline Sum Sq. Dev. & 0.089128 & 0.221821 & 0.004244 & 0.460116 \\
\hline Observations & 10 & 10 & 10 & 10 \\
\hline
\end{tabular}

SOURCE: AUTHOR'S CALCULATION, 2021 


\section{NORMALITY TEST}

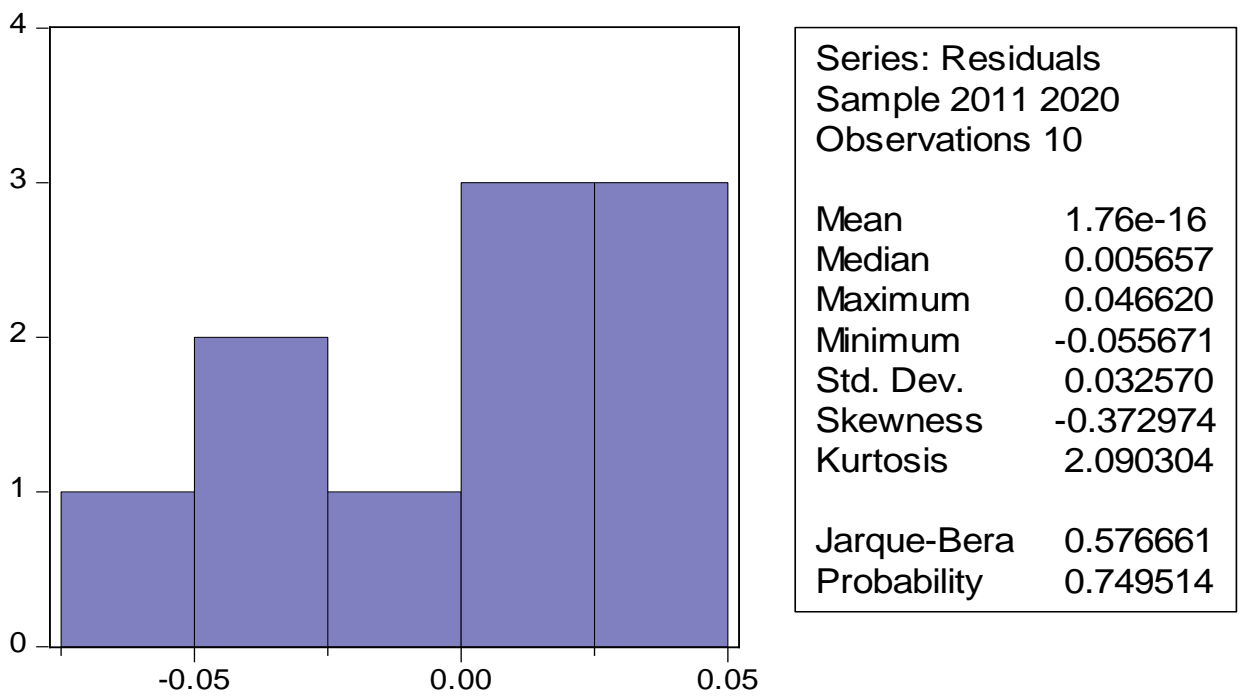

Figure 1. Histogram Normality

Table 2. Analytical Checks

\begin{tabular}{|c|c|c|}
\hline TYPE DIAGNOSTIC TESTS & F-STATISTICS & P-VALUE \\
\hline Ramsey RESET Test for Stability & 0.175 & 0.69 \\
\hline Breusch-Godfrey Serial Correlation LM Test & 0.725 & 0.54 \\
\hline Heteroskedasticity Test: Breusch-Pagan-Godfrey & 5.408 & 0.70 \\
\hline Histogram Normality Test: Jarque-Bera & 0.57 & 0.75 \\
\hline Multi-Collinearity test: & Coefficient variance & VIF \\
\hline LOG_PIT & 0.012 & 1.66 \\
\hline LOG_CPI & 0.632 & 1.69 \\
\hline LOG_INF & 0.003 & 1.04 \\
\hline
\end{tabular}

SOURCE: AUTHOR'S CALCULATION, 2021

The results of the various diagnostic tests indicate that the model selected for this study is stable, Heteroskedasticity free, and there is also absence of serial correlation and inter-correlation of independent variable as indicated by the Variance Inflation Factor (VIF).

\section{Findings}

Figure 2 shows the trend result of the variables from 2011 to 2020. The aggregate national income maintained a steady rise while the PIT varied but reached the climax in 2018. PIT started increasing from 2017 and grew very high till the drop that occurred during the periods of 2019 - 2020. It shows there was a vigorous tax drive in 2018 that led to the dramatic rising. However, the corruption level in 2017 was too high while in 2016 the inflation rate dropped tremendously. One remarkable thing is that CPI and INF fluctuations did not affect the steady rise in the gross national income as observed in Figure 2. Although, corruption and inflation are two economic issues that the country battles with, and it appears the economy continues to grow despite their existence. In this study, they were found relevant due to the possibility of inflation affecting payment of taxes. Inflation causes rise in the prices of goods and services. When such economic scenario occurs, households tend to focus more on satisfying household needs and giving little attention to payment of taxes which contribute to national income. Such situation plays out, when corrupt public officers also ignore their civic responsibility of tax payment with the mindset of defrauding the government through deliberate tax evasion.

The result on Table 3 suggests that the relationship between national aggregate income and PIT is very strong. In the same manner, the R-square of $89 \%$ gives the proof that PIT and other moderating variable could not explain only $11 \%$ of the changes in GNI. The standard error of regression shows that the study prediction is free from bias and the Durbin-Watson confirms freedom from auto-correlation. The result of the F-Statistic suggests that the model is statistically significant and all the predictor variables affect the response variable positively and materially. The study earlier suggested that PIT does not have a significant impact on Nigeria's aggregate income. Thus, the statistical result of the analysis on table 3 indicates that PIT has a significant positive impact on the 
gross national income. The findings of [7], [14], [15,] confirm this outcome of this study. On the contrary, the works of [3], [10] exhibited conflicting results. However, CPI and INF are insignificant and do not affect the

LOG GNI

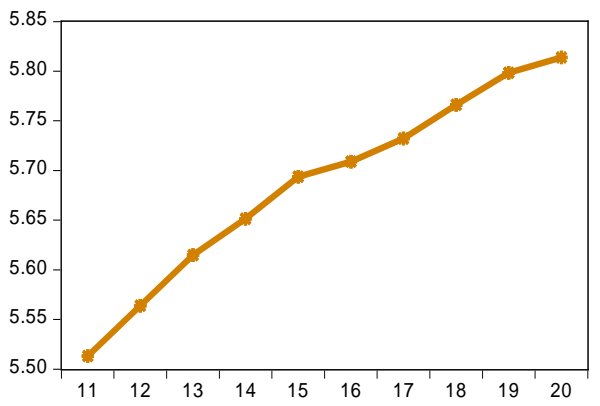

LOG CPI

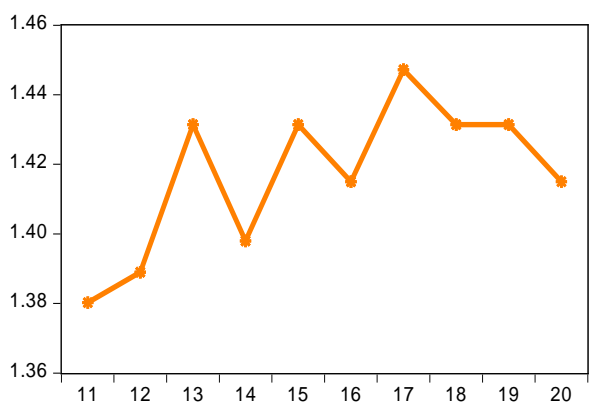

variations in the gross national revenue. Figures 2 and 3 indicate that the model is robust and valid. The appearance of the blue line between the dotted red lines provides proof that the model is stable.

LOG PIT

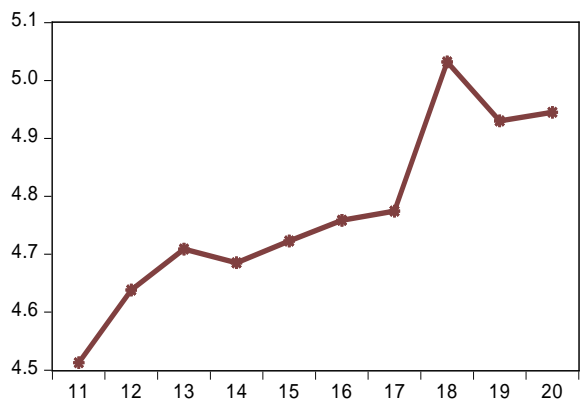

LOG INF

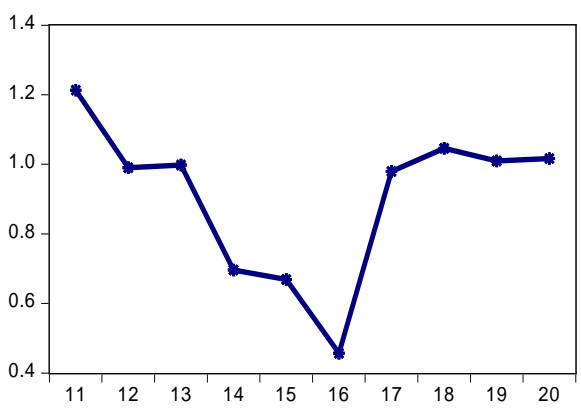

Figure 2. Trend of Data from 2011-2020

Table 3. Regression result

Dependent Variable: LOG_GNI

Method: Least Squares

Sample: 20112020

Included observations: 10

\begin{tabular}{ccccc}
\hline Variable & Coefficient & Std. Error & t-Statistic & Prob. \\
\hline LOG_PIT & 0.525152 & 0.109262 & 4.806363 & 0.0030 \\
LOG_CPI & 0.689838 & 0.795233 & 0.867467 & 0.4190 \\
LOG_INF & -0.079526 & 0.059845 & -1.328850 & 0.2322 \\
C & 2.274894 & 0.904074 & 2.516270 & 0.0455 \\
\hline R-squared & 0.892885 & Mean dependent var & 5.685640 \\
Adjusted R-squared & 0.839327 & S.D. dependent var & 0.099514 \\
S.E. of regression & 0.039889 & Akaike info criterion & -3.316237 \\
Sum squared resid & 0.009547 & Schwarz criterion & -3.195203 \\
Log likelihood & 20.58119 & Hannan-Quinn criter. & -3.449011 \\
F-statistic & 16.67146 & Durbin-Watson stat & 2.086035 \\
Prob(F-statistic) & 0.002578 & & \\
\hline
\end{tabular}

SOURCE: AUTHOR'S CALCULATION, 2021 
ROBUSTNESS CHECK

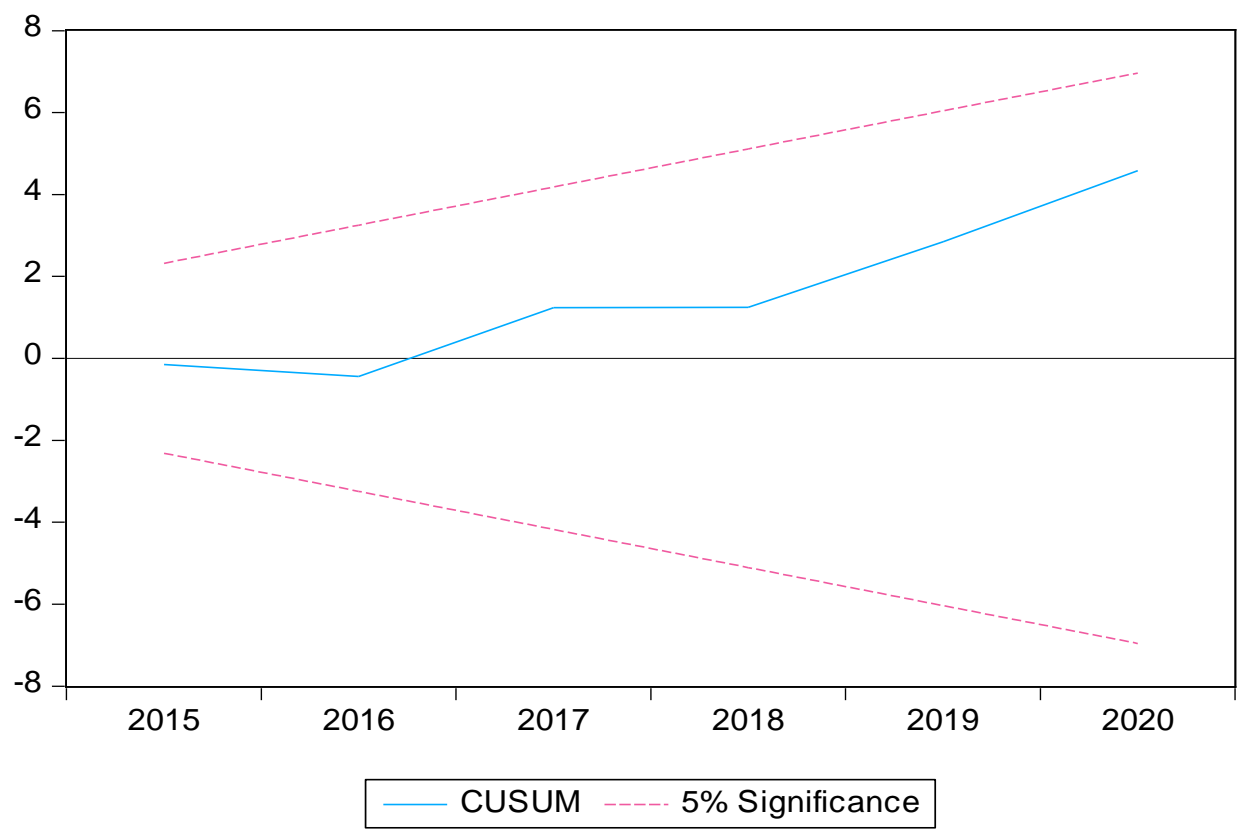

Figure 2. Recursive estimates of the CUSUM test. CUSUM = Cumulative Sum Control Chart

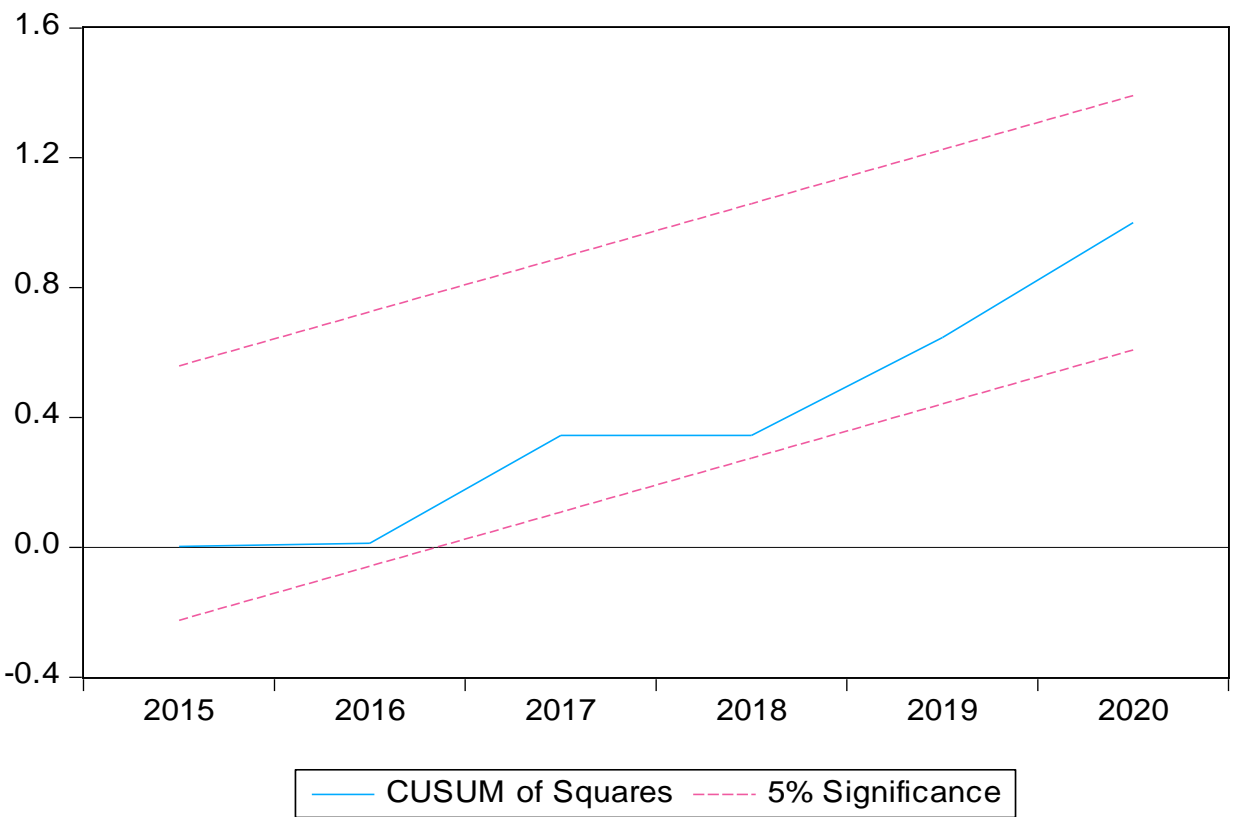

Figure 3. Recursive estimates of CUSUM of squares test. CUSUM = Cumulative Sum Control Chart

The robustness check reveals the stability of the regression model with the appearing of the blue dotted lines between the frontiers of the red dotted lines.

\section{Conclusions}

The study examines the influence of personal income tax on gross national income of Nigeria for a decade which span from 2011 to 2020. Personal income tax in
Nigeria is a tax levied on individuals' income from employment or business ventures. As part of the originality of this study, corruption and inflation are used as control variables while gross national income serves as the response variable. The findings reveal that PIT contributes significantly to the total income of the country. The policy implication is that when the government revenue increases, expenditure responsibilities of the government will be enhanced. The public will receive better welfare services from the government as their own 
reward for tax morality and civility. As put forward by [17], tax morality can also be achieved through religious teaching which the members might uphold in ensuring that tax evasion is curbed in a nation. Therefore, the study suggests improvement in personal income tax administration to enhance PIT collection from the qualifying individuals. However, this study used PIT collected at the Federal Government level which includes PIT from Federal Government Agencies, Armed Forces and Police Personnel, Foreign Service Officers and Residents of the Federal Capital Territory, Abuja. Thus, the study suggests more research work on PIT effect on the economy using both the PIT at the Federal and State Government levels.

\section{Acknowledgement}

The open access support of this article by Covenant University is well appreciated by the authors.

\section{REFERENCES}

[1] Omodero, C.O., \& Dandago, K.I. (2019). Tax revenue and public service delivery: Evidence From Nigeria. International Journal of Financial Research, 10(2), 82-91. DOI:10.5430/ijfr.v10n2p82.

[2] Korkmaz, S., Yilgor, M., \& Aksoy, F. (2019). The impact of direct and indirect taxes on the Growth of the Turkish economy. Public Sector Economics, 43(3), 311 - 323. http://doi.org/10.3326/pse.43.3.5.

[3] Palic, I., Zmuk, B., \& Grofelnik, B. (2017). The long-run impact of personal income taxation on economic development: Evidence from Croatia. Croatian Review of Economic, Business and Social Statistics, 3(1), 35-44. DOI: 10.1515/crebss.

[4] Szarowska, I. (2014). Personal Income Taxation in a context of a tax structure. Procedia Economics and Finance, 12(1), 662 - 669. DOI: 10.1016/52212-5671(14)00391-8.

[5] Kalaš, B., Mirović, V., \& Andrašić, J. (2017). Estimating the Impact of Taxes on the Economic Growth in the United States. Economic Themes, 55(4), 481-499. https://doi.org/10.1515/ethemes-2017-0027.

[6] Nonvide, G.B.T, \& Amegnaglo, C. (2017). Effect of Tax Revenues on Economic Growth in Benin: The Role of
Investment. Journal of Advanced Studies in Finance, 8(2), 139-145.

[7] Stoilova, D. (2017). Tax structure and economic growth: Evidence from the European Union. Contaduria $y$ Administracion, 62(1), 1041 - 1057.

[8] Cornia GC, Johnson RB, Nelson RD. Personal Income Tax Revenue Growth and Volatility: Lessons and Insights from Utah Tax Reform. Public Finance Review. 2017;45(4):458-483. doi : 10.1177/1091142116668255

[9] Amin, A., Chen, Y., \& Huang, S. (2018). Personal Income Tax and economic growth. A Comparative study between China and Pakistan. Asia Journal of Economic Modelling, 6(1), 65-73. DOI:: 10.18488/journal.8.2018.61.65.73.

[10] Baltais, O., \& Brakis, R. (2018). The effect of personal income tax progressivity on output Volatility: the role of non-linearity. A Bachelor Thesis submitted to Stockholm School of Economics, RIGA.

[11] Mcnabb, K. (2018). Tax structures and economic growth: New evidence from the government Revenue dataset. Journal of International Development, 30(1), 173 - 205. DOI: 10./002/jid-3345.

[12] Neog, Y., \& Gaur, A.K. (2020). Tax structure and economic growth: a study of selected Indian States. Journal of Economic $\quad$ Structures, $\quad 9(38)$, 1-12. https://doi.org/10.1186/s40008-020-00215-3.

[13] Egbunike, F.C., Emudainohwo, O.B., \& Gunardi A. (2018). Tax Revenue and Economic Growth: A Study of Nigeria and Ghana. Jurnal Ilmu Ekonomi, 7(2), 213-220. https://doi.org/10.15408/sjie.v7i2.734.

[14] Adeyemi, A.A., \& Mieseigha, E.G. (2019). Personal Income Tax (PIT) and economic growth in Nigeria: A Vector Autoregression (VAR) Analysis. Trends Economics and Management, 33(1), 9-18. http://dx.doi.org/10.13164/trends.2019.33.9.

[15] Ade, O.J., Adegbie, F.F. (2020). Personal Income Tax and infrastructural development in Lagos State, Nigeria. Journal of Finance and Accounting, 8(6), 276-287. DOI: 10.11648/j.jfa.20200806.14.

[16] Shahbaz, M., Loganathan, N., Muzaffan, A.T., Ahmed, K., \& Jabran, M.A. (2016). How Urbanization Affects CO2 Emissions in Malaysia? The Application of STIRPAT model. Renewable and Sustainable Energy Reviews, 57, 83-93. https://doi.org/10.1016/j.rser.2015.12.096

[17] Ishak, A.I., \& Ali, M.M. (2020). Factors influencing intention to participate in tax evasion: Individual perspectives. Universal Journal of Accounting and Finance 8(4), 103-114. DOI: 10.13189/ujaf.2020.080403. 